\title{
The Influence of Financial Distress and Independence of Board of Commissioners on Tax Aggressiveness
}

\author{
Galih Prima Dhamara ${ }^{1}$, Evony Silvino Violita ${ }^{{ }^{*}}$ \\ ${ }^{1}$ Faculty of Economics and Business, Universitas Indonesia, Depok 16424, Indonesia \\ *evony.silvino@gmail.com
}

\begin{abstract}
This research aims to examine the influence of financial distress and the independence of boards of commissioners on tax aggressiveness. The study uses 97 manufacture firms listed on the Indonesia Stock Exchange from 2010 to 2013. Using a regression method, the findings show that the financial distress and independence of boards of commissioners have no significant influence on tax aggressiveness. High corporate governance scores do not guarantee a good practice. This research also proves that financial distress has no moderating effect on the association between commissioner independence and tax aggressiveness, since the independence of boards of commissioners does not have a significant effect on tax aggressiveness.
\end{abstract}

Keywords: Financial Distress; Independence of Board of Commissioners; Tax Aggressiveness.

\section{INTRODUCTION}

As profit-oriented entities, firms will always attempt to increase their profitability. This is done by increasing their revenue or decreasing their expenses, including tax expenses. In order to reduce the amount of tax paid, firms tend to lower their income before tax by involving tax aggressiveness activities, which comprise management's effort to lower their firm's income before taxes through various tax planning strategies. ${ }^{1-3}$

Previous research shows that management has incentives to carry out tax aggressiveness activities, even if there are marginal benefits. ${ }^{4,5}$ Financial distress could be considered one such incentive for pursuing tax aggressiveness activities, as financial constraints faced by a firm increase the marginal benefits of tax saving, and exceed its marginal costs ${ }^{6}$. On the other hand, a higher proportion of external directors can reduce tax aggressiveness activities. It is argued that this negative effect may occur when a firm involves in tax aggressiveness activities at the extreme level ${ }^{7}$.

When a firm faces financial distress, the controlling and monitoring functions of external directors, particularly around tax aggressiveness activities, can be diluted or even vanish. Since financial distress leads to going concern threats for the firm, boards of commissioners - since they are one such party that has interests in the firm - want to ensure that the firm is still able to meet its liabilities. This implies that the board of commissioners' performance benefits the debtors further, since they are prioritized over shareholders in terms of residual claims. ${ }^{8}$

This research aims to examine the influence of financial distress and the independence of boards of

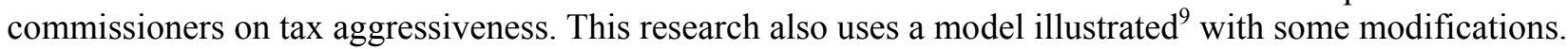

The study finds that financial distress and independence of boards of commissioners have no significant influence on tax aggressiveness. This is owing to the fact that this research does not cover the financial crisis period that may amplify the chance of financial distress. This research also proves that financial distress has no moderating effect on the influence of commissioner independence on tax aggressiveness.

The paper is organized as follows. In section 2, the hypotheses are developed. In section 3, research methods are given. In section 4, the research result is presented. Finally, the findings of the paper are summarized in the last section.

\section{LITERATURE REVIEW AND HYPOTHESIS DEVELOPMENT}

It is claimed that financial barriers increase the marginal benefit of tax savings, compared with the marginal costs generated by those activities. ${ }^{6}$ Companies facing financial distress will deal with an increasing cost of capital, decreasing access to financial sources, lower credit rating, and a general willingness to take a higher risk by managers, which alters management perspectives on tax aggressiveness. In this condition, few options will propel companies to increase the level of its tax aggressiveness. Tax aggressiveness therefore becomes a more likely route taken, since tax expense is a significant cash outflow for companies facing financial distress. As a result of the latter, they are prone to disregard possible reputation risks.,

Additionally, a company may presume that risk - whether it is coming from tax audits or possible reputation damage - is not significant during the period. ${ }^{10}$ Tax savings can generate the capital needed to finance a company's operation, maintain its credit rating, satisfy debt covenants, and mitigate risk. ${ }^{11}$ Similarly, the results of 
a study conducted also indicate that financial distress has a positive relationship with tax aggressiveness. ${ }^{9}$

$\mathbf{H}_{1}$ : Financial distress has a positive relationship with tax aggressiveness.

A higher proportion of external directors can improve the effectiveness of those overseeing management, as well as enhancing compliance. ${ }^{12-14}$ In conjunction with company tax aspects, it is revealed that a negative relationship may occur between the independence of external directors and tax aggressiveness. ${ }^{9}$ This suggests that a board of commissioners with greater indep

endence may prevent tax aggressiveness through effective monitoring.

$\mathbf{H}_{2}$ : The independence of board of commissioners has a negative relationship with tax aggressiveness

The benefit of better monitoring conducted by outside directors will decrease or even vanish during financial distress. In a bankrupt situation, the board of commissioners' performance benefits the debtors since they are prioritized more than its shareholders in residual claims. ${ }^{8}$ The decreasing marginal benefit resulted from an implementation of corporate governance in a company facing financial distress will dilute or even remove the monitoring function conducted by independent commissioners. Consequently, in the research, findings corroborate that there is a significant negative relationship between financial distress and outside directors' performance levels.

Furthermore, as a party which has an interest in a company, the board of commissioners is also willing to ensure company's performance. The members inside the board will therefore be more focused on matters related to the going concern of the company itself. The diluted monitoring function caused by the board of commissioners will provide opportunities to management for pursuing tax aggressiveness related activities. In addition, financial distress is likely to weaken the negative effect of external directors on tax aggressiveness. ${ }^{9}$

$\mathbf{H}_{3}$ : Financial distress is a moderating variable weakening the negative effect of the independence of the board of commissioners on tax aggressiveness.

\section{RESEARCH METHOD}

The model used in this research is a replication from Richardson ${ }^{9}$ with several modifications. Model to test hypothesis 1 and 2 is as follows:

TAGi, $=\alpha 0+\beta$ FDISTRESSi,t $+\beta$ INDPNDi,t $+\beta 3$ SIZEi,t-1 $+\beta$ CCAPINTi,t $+\beta$ 5ROAi,t + $\beta 6$ MKTBKi,t-1 + $\beta$ 7RDi,t-1 + $\beta 8$ CHANGELCFi,t-1 + $\varepsilon i, t$

The model to examine the hypothesis 3 :

TAGi, $=\alpha 0+\beta 1$ FDISTRESSi,t $+\beta$ INDDPNDi,t $+\beta$ 3INDPND*FDISTRESSi,t $+\beta$ 4SIZEi,t- $1+$ $\beta 5$ CAPINTi,t $+\beta 6$ ROAi, $t+\beta 7$ MKTBKi,t-1 + $\beta 8$ RDi,t-1 + $\beta$ CCHANGELCFi,t-1 + $\varepsilon i, t$

Where TAGi,t is Tax aggressiveness, Cash Effective Tax Rate and Tax Sheltering; FDISTRESSi,t is Financial distress (Modified Altman Z Score); INDPNDi,t is The level of independence of the board of commissioners (scoring results); SIZEi,t-1 is Company size (natural logarithm of total assets-beginning of year), CAPINTi,t is Capital intensity (fixed assets to total assets); ROAi,t is Return on Asset; MKTBKi,t1 is Market-to-book ratio; RDi,t-1 is Research and Development (research and development expense /total assets); CHANGELCFi,t-1 is Change in Loss Carry Forward (change of loss carry forward/total assets).

Tax aggressiveness is reflected in two proxies - cash effective tax rate (CASHETR) and tax sheltering (SHELTER). CASHETR is calculated by dividing cash outflows related tax expense to income before tax. This proxy is chosen in line with the statement that company is willing to restrict cash outflows in a bid to fulfill its obligation to creditors. The lower CASHETR suggests the higher level of tax aggressiveness in a company.

On the other hand, SHELTER is used to measure the likelihood of company in dealing with tax sheltering activities. ${ }^{15}$ The higher level of SHELTER means that the probability of a company dealing with those activities - tax sheltering — will be greater as well. The formula used to calculate SHELTER is written below:

SHELTER $=-4.30+6.63 *$ BTD $-1.72 *$ LEV $+0.66 *$ SIZE $+2.26 *$ ROA $+1.62 *$ FOREIGN_INCOME $+1.56 *$ RD

Whereby BTD is the difference between accounting and fiscal profit divided by total assets, SIZE $=$ logarithm of total assets, ROA is net income divided by total assets; FOREIGN_INCOM is dummy variable, 1 if the company has any overseas income and 0 otherwise; and RD is research and development expense divided by total assets.

Independent variables used in this research are financial distress and the independence of the board of commissioners. Financial distress is measured by using the proxy of Modified Altman Z-Score. ${ }^{16}$ Nonetheless, this paper operates Altman Z-Score which has been modified by constructed as the 
following ${ }^{17}$ :

$\mathrm{Z}$ Score $=1,2$ (working capital/total assets) $+1,4$ (retained earnings/total asset) $+3,3$ (income before interest and tax expense/total asset) +1 (sales/total asset)

The lower Z-score suggests the higher level of financial distress of a company. ${ }^{16}$ In order to be consistent with the hypothesis which has been developed earlier, this research modifies Z-score by dividing its value with -1. It thus implies that the higher modified $\mathrm{Z}$ score increases the risk of financial distress in a company.

The independence level of the board of commissioners is calculated based on the component of independence by Hermawan ${ }^{18}$ scoring index. This index is constructed according to the list of questions constructed by the Indonesian Institute for Corporate Directorship (IICD), with some modifications. For each scoring criteria, any good indication will be given score 3, fair 2, and poor 1 . Specifically, for questions whose information cannot be gained, a score of 1 will be given.

As mentioned earlier, the level of independence of the board of commissioners is only measured by using the component of independence taken from the effectiveness of the board of commissioners scoring index. This component consists of six indicators ${ }^{18}$, they are:

The proportion of independent commissioners: a higher proportion of independent commissioners in a company is expected to increase the effectiveness of monitoring performed by the board of commissioners. The board of commissioners is thus able to force management to reduce the activities related to tax aggressiveness. Scoring criteria: this is classified as good if the proportion of independent commissioners is more than $50 \%$; fair if the proportion of independent commissioners is between $30 \%$ and $50 \%$; poor if the proportion of independent commissioners is less than $30 \%$.

The president commissioner is also an independent commissioner: if the president commissioner is also the independent commissioner, a decision taken by those amongst the board is expected to be more objective and independent, including any decision to avoid tax aggressiveness related activities. There is an interaction effect between the composition of the board of commissioners and the independence of the president commissioner. ${ }^{19}$ Scoring criteria: this is seen as good if the president commissioner is an independent commissioner; poor if the president commissioner is not an independent commissioner.

The company's annual report reveals the definition of the independence of independent commissioners as previously stated by Indonesia Stock Exchange and OJK Scoring criteria: good if there is a clear statement regarding the definition of independence for independent commissioners, in line with the definition stated by BEI and OJK; poor if there is no clear statement regarding the definition of independence for independent commissioners, in line with the definition stated by BEI and OJK.

Proportion of commissioners working in shareholder companies or any affiliated companies: with a smaller proportion of members working in those companies, it is predicted that the board of commissioners is able to control management performance, particularly for an attempt to reduce tax aggressiveness-related activities. Scoring criteria: good if the proportion of commissioners working in shareholders' companies or any affiliated companies is less than $30 \%$ (considering the BEI instruction about minimum portion of independent commissioners), fair if the proportion of commissioners working in shareholders' companies or any affiliated companies is between $30 \%$ and $50 \%$ (the proportion which is not better off since the value exceeds $30 \%$ ); poor if the proportion of commissioners working in shareholders companies or any affiliated companies is more than $50 \%$. This means that the proportion of the board of commissioners is significant and is likely to weaken the independence of the board of commissioners.

The company has a nomination and remuneration committee in its corporate governance practices: the presence of its committee is expected to help corporate governance practices to be effective. The nomination committee in a company has a duty to elect the board of commissioners and directors in an independent and professional manner. Meanwhile, the remuneration committee is expected to set an appropriate remuneration amount for directors and commissioners with the purpose of improving their performance. Scoring criteria: good if the company has both nomination and remuneration committee; fair if the company only has one committee, either nomination or remuneration committee; poor if the company does not have any committees in its corporate governance practices.

The length of becoming a member of the board of commissioners: the longer a person serves their duty as a commissioner in a company, the further their objectivity and independence will be reduced in performing this duty. The results of research conducted by Anderson et al. ${ }^{20}$ indicate that board tenure measured by the average length of service of the board of commissioners has a positive and significant relationship on the cost of debt. Scoring criteria: good if the average length of service as a commissioner is up to 5 years; fair if the average length of service as a commissioner falls between 5 and 10 years; poor 
if the average length of service as a commissioner is more than 10 years. The sum of all scoring is divided by 18; the highest score of independence may be obtained to gain an understanding of the level of independence of commissioners in a company.

The control variable company size (SIZE) is used as bigger companies tend to pay a higher political cost, including income tax ${ }^{21}$ and often participate in tax planning ${ }^{22}$. Capital intensity (CAPINT) measuring the differences of commercial and tax reporting which could affect tax aggressiveness ${ }^{23}$. Return on assets (ROA) explains that a company which has a higher profitability tends to also have a higher effective tax rate.

Market to book ratio (MKTBK) is used as a growing company is prone to buy a profitable asset from tax side ${ }^{8}$. Change of loss carry forward (CHANGELCF) indicates that fiscal loss in a prior year could decrease fiscal profit in a current year. The last control variable is Research and Development $(\mathrm{R} \& \mathrm{D})$, which is used to measure the difference reporting between commercial and tax purpose, coming from the different treatments of accounting and tax on research and development expense ${ }^{23}$.

\section{RESULTS AND DISCUSSION}

The regression result of model 1 shows that financial distress has no significant impact on tax aggressiveness. This result does not align with previous research conducted by Richardson et al. ${ }^{9}$, which illustrates that financial distress correlates positively with tax aggressiveness.

Table.1. Regression Result of Model 1

\begin{tabular}{|c|c|c|c|c|c|c|}
\hline \multicolumn{7}{|c|}{$\begin{array}{l}\text { TAGi,t }=\alpha_{0}+\beta_{1} \text { FDISTRESS }_{\mathrm{i}, \mathrm{t}}+\beta_{2} \text { INDPND }_{\mathrm{i}, \mathrm{t}}+\beta_{3} \mathrm{SI}_{2} \\
\beta_{6} \text { MKTBK }_{\mathrm{i}, \mathrm{t}-1}+\beta_{7} \mathrm{RD}_{\mathrm{i}, \mathrm{t}-1}+\beta_{8} \text { CHANGELCF } \\
\mathrm{i}, \mathrm{t}-1+\varepsilon_{\mathrm{i}, \mathrm{t}} \\
\text { CASHETR: Prob } \mathrm{F}=0.1520 ; \text { R-squared }=0.0466 \\
\text { SHELTER: Prob } \mathrm{F}=0.0000 ; \text { R-squared }=0.3242\end{array}$} \\
\hline \multirow{2}{*}{ Variable } & \multicolumn{3}{|c|}{ CASHETR } & \multicolumn{3}{|c|}{ SHELTER } \\
\hline & Pred. & Koef. & $p$-value & Pred. & Koef. & $p$-value \\
\hline FDISTRESS & - & 0.014 & 0.289 & + & -0.090 & 0.137 \\
\hline INDPND & + & -0.196 & 0.163 & - & -0.622 & 0.191 \\
\hline SIZE & - & 0.026 & 0.039 & + & 1.875 & $0.000 * * *$ \\
\hline CAPIN & - & -0.227 & 0.019 & + & 0.773 & $0.012^{* *}$ \\
\hline ROA & - & 0.256 & 0.154 & + & 4.671 & $0.000^{* * *}$ \\
\hline MKTBK & - & -0.003 & 0.369 & + & 0.054 & $0.023^{* *}$ \\
\hline $\mathrm{RD}$ & - & -6.903 & 0.301 & + & -67.053 & 0.203 \\
\hline CHANGELCF & + & 0.329 & 0.302 & - & -0.287 & 0.427 \\
\hline $\mathrm{C}$ & $?$ & -0.200 & 0.309 & ? & -48.970 & 0.000 \\
\hline
\end{tabular}

The present research covers the 4 year period from 2010 until 2013, which does not include the global financial crisis period, in order to avoid the effects of crisis on financial distress.

In addition, the independence of the board of commissioners has no significant effect on tax aggressiveness. This result is inconsistent with Richardson et al. ${ }^{9}$, who argue that external directors significantly negatively correlate with tax aggressiveness. On the other hand, this study's findings are consistent with other research conducted in Indonesia. Ridha ${ }^{24}$ has proven that corporate governance, of which the board is just one of the components, does not have a significant effect on tax aggressiveness activities carried out by Indonesian companies.

This argument also aligns with research carried out by Siregar and Utama ${ }^{25}$. The authors confirm that corporate governance in Indonesia arises from rules stipulating its importance, rather than companies' inherent commitments to have better corporate governance practices. A higher corporate governance score does not guarantee better practice. Hence, many previous studies are unable to prove the effect of corporate governance on firms' tax management practices.

Meanwhile, the regression result of model 2 shows that there is no moderating effect of financial distress on the influence of the independence of boards of commissioners on tax aggressiveness. This finding is inconsistent with Richardson et. $\mathrm{al}^{9}$. Based on the regression result of model 1 , the independence of the board of commissioners has no significant effect on tax aggressiveness, owing to the fact that corporate governance in Indonesia does not arise from the company's commitment itself. As that effect is not significant, the moderating effect of some variables on the influence of financial distress on tax aggressiveness could not be proven. Thus, hypothesis 3 is rejected.

On the other hand, all control variables have a significant effect on tax aggressiveness as 
expected, except for research and development expenses and change of loss carried forward. Research and development expenses have a significant negative effect on tax aggressiveness. There is a possibility that research and developments are not conducted in a fair amount, thus they could not be considered deductible expenses in determining the taxable income. Besides, it is possible that deductible research and development expenses could increase a chance of overpayment, so that companies become reluctant to conduct research and developments, as has happened in China ${ }^{26}$. Change of loss carried forward has no significant effect on tax aggressiveness. This implies that the utilization of loss carried forward by companies is not intended as a tax aggressiveness activity.

\section{CONCLUSION}

This research shows that financial distress has no significant effect on tax aggressiveness. This is due to the fact that this research does not cover the financial crisis period that may amplify the chance of financial distress. Furthermore, this research has proven that independence of board of commissioners has no significant effect on tax aggressiveness. High corporate governance scores do not guarantee a good practice. Moreover, there is no prove that financial distress has moderating effect on the correlation between independence of board of commissioners and tax aggressiveness since independence of board of commissioners does not have significant effect on tax aggressiveness.

Table.2. Regression Result of Model 2

\begin{tabular}{|c|c|c|c|c|c|c|}
\hline \multicolumn{7}{|c|}{ 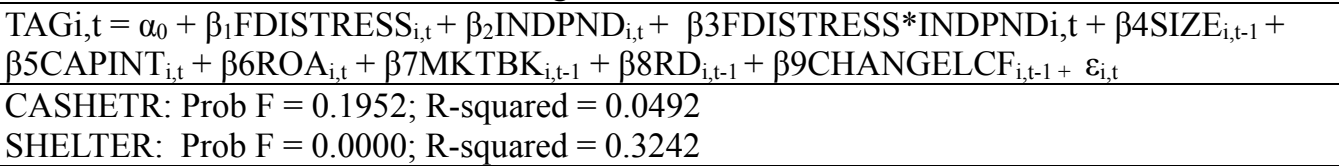 } \\
\hline \multirow{2}{*}{ Variable } & \multicolumn{3}{|c|}{ CASHETR } & \multicolumn{3}{|c|}{ SHELTER } \\
\hline & Pred. & Koef. & $p$-value & Pred & Koef. & $p$-value \\
\hline FDISTRESS & - & 0.116 & 0.095 & + & 0.294 & 0.200 \\
\hline INDPND & + & -0.568 & 0.062 & - & -2.119 & $0.083^{*}$ \\
\hline FDISTRESS*INDPND & - & -0.180 & 0.115 & + & -0.672 & 0.123 \\
\hline SIZE & - & 0.025 & 0.050 & + & 1.885 & $0.000 * * *$ \\
\hline CAPIN & - & -0.235 & 0.017 & + & 0.795 & $0.021 * *$ \\
\hline ROA & - & 0.282 & 0.133 & + & 4.742 & $0.000 * * *$ \\
\hline MKTBK & - & -0.001 & 0.465 & + & 0.046 & $0.150 * *$ \\
\hline $\mathrm{RD}$ & - & -9.497 & 0.240 & + & -81.327 & $0.030 * *$ \\
\hline CHANGELCF & + & 0.310 & 0.312 & - & -0.472 & 0.421 \\
\hline $\mathrm{C}$ & $?$ & 0.062 & 0.446 & $?$ & -48.392 & 0.000 \\
\hline
\end{tabular}

\section{REFERENCES}

[1] S. O. Rego. Tax-aggressiveness activities of us multinational firms. Contemporary Accounting Research, 20(4)(2003) $805-$ 833.

[2] M. M. Frank, J. L. Lynch, S. O. Rego. Are financial and tax reporting aggressiveness reflective of broader corporate policies?, The Accounting Review, 84(2)(2009) 467-496.

[3] S. Chen, X. Chen, Q. Cheng, T. Shevlin. Are family firms more tax aggressive than non-family firms?, Journal of Financial Economics, 95(2010) 41-61.

[4] D. A. Shackelford, T. Shevlin. Empirical tax research in accounting, Journal of Accounting and Economics, 31(2001) 321387.

[5] M. Scholes, M. A. Wolfson. Taxes and Business Strategy: A Planning Approach Third Edition, Pearson Prentice Hall, Upper Saddle River, NI (2005).

[6] A. Edwards, C. Schwab, T. Shevlin. Financial constraints and the incentive for tax planning. Working Paper, SSRN (2013).

[7] C. Armstrong, J. Blouin, A. Jagolinzer, D. Larcker. Corporate governance, incentives and tax avoidance. Working Paper, University of Pennsylvania, Pennsylvania (2013).

[8] H. I. Chou, H. Li, X. Yin. The effects of financial distress and capital structure on the work effort of outside directors. Journal of Empirical Finance, 17(2010) 300-312.

[9] G. Richardson, R. Lanis, G. Taylor. Financial distress, outside directors and corporate tax aggressiveness spanning the global financial crisis: an empirical analysis. Journal of Banking and Finance, 52(2015) 112-119.

[10] A. S. Koch. Financial distress and the credibility of management earnings forecasts. GSIA Working Paper No. 2000-10 (2000).

[11] J. Brondolo. Collecting taxes during an economic crisis: challenges and policy options. IMF Staff Position Note (SPN/09/17) (2009).

[12] M. L. Mace. Directors: Myth and Reality, Harvard Business School Press, (1979).

[13] S. Finkelstein, A. Mooney. Not the usual suspects: how to use board process to make boards better. Academy of 
Management Executive, 17(2)(2003) 101-113.

[14] R. B. Adams and D. Ferreira. A theory of friendly boards. Journal of Finance, 62(1)(2007) 217-250.

[15] R. Wilson. An examination of corporate tax shelter participants. The Accounting Review, 84(3)(2009) 969-999.

[16] E. I. Altman. Financial ratios, discriminate analysis, and the prediction of corporate bankruptcy. Journal of Finance, 23(1968) 589-609.

[17] J. R. Graham, M. Lemmon, J. Schallheim. Debt, leases and the endogeneity of corporate tax status. Journal of Finance, 53(1998) 131-162.

[18] A. A. Hermawan. Pengaruh efektivitas dewan komisaris dan komite audit, kepemilikan keluarga, dan peran monitoring bank terhadap kandungan informasi laba. Dissertation, Universitas Indonesia (2010).

[19] J. W. Coles, W. S. Hesterly. Independence of the chairman and board composition firm choices and shareholder value. Journal of Management, 26(2)(2000) 195-214.

[20] K. L. Anderson, D. N. Deli, S. L. Gillan, Board of directors, audit committees, and the information content of earnings. Working Paper Series, University of Delaware (2003).

[21] R. L. Watts, J. L. Zimmerman. Towards a positive theory of the determinants of accounting standards, Prentice Hall, New Jersey, (1986).

[22] J. Siegfried. The relationship between economic structure and the effect of political influence: empirical evidence from the federal corporation income tax program. Ph.D. Dissertation, University of Wisconsin (1972).

[23] S. Gupta, K. Newberry. Determinants of the variability in corporate effective tax rates: evidence from longitudinal data. Journal of Accounting and Public Policy, 16(2012) 1-34.

[24] M. Ridha. Analisis terhadap agresivitas pajak, agresivitas pelaporan keuangan, kepemilikan keluarga, dan tata kelola perusahaan di Indonesia. Undergraduate Thesis, Universitas Indonesia (2014).

[25] S. V. Siregar, S. Utama. Type of earnings management and the effect of ownership structure, firm size, and corporategovernances practices: evidence from Indonesia. The International Journal of Accounting, 43(2005) 1-27.

[26] C. S. Lennox, L. Wanfu, B. Lin, Z. T. Wang. Tax aggressiveness, R\&D spending and firms' claims for R\&D tax deductions: Evidence from China. Working Paper, SSRN (2015). 